\title{
GENOTOXICITY OF SOME PLANT ESSENTIAL OILS IN COTTON LEAFWORM, SPODOPTERA LITTORALIS (LEPIDOPTERA: NOCTUIDAE): THE POTENTIAL ROLE OF DETOXIFICATION ENZYMES
}

\author{
Yasmin Adel Fergani $^{1}$; Heba Mahmoud Elbanna ${ }^{1}$; \\ Heba Mohamed Hamama ${ }^{2 *}$ \\ ${ }^{1}$ Plant Protection Research Institute, Agriculture Research Center, Giza, Egypt \\ ${ }^{2}$ Entomology Department, Faculty of Science, Cairo University, Giza, Egypt
}

\section{Article History:}

Received: 20 April 2020

Revised: 03 June 2020

Accepted: 04 June 2020

Published Online:

09 June 2020

\section{Keywords:}

Acetylcholinesterase

Bio-insecticides

Carboxylesterase

Comet assay

Glutathione S-transferase

*Correspondence:

Heba Mohamed Hamama

Entomology Department

Faculty of Science

Cairo University

Giza, Egypt

E-mail:

Hahmed@sci.cu.edu.eg

\begin{abstract}
Increasing incentives for discovering effective and eco-friendly bio-insecticides seem to be a very important challenge nowadays. Plant essential oils play a promising role in integrated pestmanagement programs. In the present study, the insecticidal activities of six essential oils from clove (Syzygium aromaticum), crane's-bills (Geranium sp.), citronella (Cymbopogon sp.), dill (Anethum graveolens), cinnamon (Cinnamomum camphora) and basil (Ocimum basilicum) were investigated against the cotton leafworm, Spodoptera littoralis "Boisduval" (Lepidoptera: Noctuidae). The toxicity test revealed that all the tested essential oils have noticeable insecticidal activity. The basil oil was the most efficient against the $3^{\text {rd }}$ instar larvae, with the lethal concentration (LC) $)_{50}=0.42 \%$; while the dill oil showed higher toxicity than the other oils against the $5^{\text {th }}$ instar larvae $\left(\mathrm{LC}_{50}=0.49 \%\right)$ after 48 hours of treatment. The impact of the tested essential oils on the acetylcholinesterase (AChE), carboxylesterase (CE), and glutathione S-transferase (GST) activities was also assessed. The basil oil induced the activity of AChE in both the $3^{\text {rd }}$ and the $5^{\text {th }}$ instar larvae. All tested oils elevated GST activity in the $5^{\text {th }}$ instar larvae, except citronella oil. The dill oil decreased CE activity in both instars. Genotoxicity analysis using comet assay revealed that all assay parameters differed significantly, compared to the control. The maximum percentage of damaged DNA was detected in larvae treated with basil followed by dill, cinnamon, clove, citronella and crane's-bills, respectively. It was concluded that these essential oils could play a promising role in controlling $S$. littoralis and providing a biological alternative to synthetic insecticides in the control programs.
\end{abstract}

\section{INTRODUCTION}

The cotton leafworm, Spodoptera littoralis, is a major pest that causes severe damage to a large number of economic crops in Egypt.
It attacks numerous economically-important crops such as cotton, rice, sugarcane, and wheat throughout the year decreasing crop yields up to $100 \%$ in greenhouses and 
fields ${ }^{[1]}$. In the past, control of lepidopterous insects depended intensely on the synthetic chemical insecticides, which pose risk on human health, causing environmental contamination in addition to increasing the elaboration of resistance to the most common insecticides that have been used effortfully for long-time ${ }^{[1]}$. The search for safe and effective new strategies is becoming crucial with emphasis on botanical insecticides ${ }^{[2]}$. Plant extracts, especially the essential oil fraction, have been advocated as possible control agents against various insect pests for being selective, biodegradable, and non-toxic products with lower impact to non-target organisms and environmentally safe ${ }^{[3]}$. They represent secondary metabolites, including terpenoids, alkaloids or flavonoids ${ }^{[4]}$. They were an efficient control method when integrated into control programs ${ }^{[5]}$. Most of the essential oils establish intense larval toxicity, developmental delay, repellency, and feeding disorders to insects ${ }^{[6]}$. As insects could not generally develop resistance to essential oils $^{[7]}$, the later was evaluated intensively against plant chewing and sucking insect pests, stored product pests, health pests, and honey bee parasitic mites ${ }^{[8]}$.

Insects respond to essential oils' toxic action either through modulating detoxification enzyme activity or increasing target site insensitivity, as in nerve conduction enzyme "acetylcholinesterase (AChE)" Thus, the estimation of enzyme activity may elucidate its insecticidal mechanism ${ }^{[10]}$. The most common metabolic detoxification mechanisms involved AChE, glutathione S-transferase (GST), and carboxylesterase $(\mathrm{CE})^{[11]}$. Effect of essential oils on detoxification enzyme activities was evaluated in Helicoverpa armigera, Trichoplusia ni, and Paederus fuscipes ${ }^{[7,9,11]}$. The activities of AChE, CE, and GST showed a possible link to oil treatment even at low-toxicity level $^{[7,9,11]}$.

Considering the genotoxic effect of plant essential oils, the clove oil showed an effect on gametogenesis in Spodoptera frugiperda ovarioles, thus affecting its reproductive capacity $^{[12]}$. DNA damage also was estimated in Culex quinquefasciatus using essential oil of Psoralea corylifolia with larvicidal and adulticidal effect ${ }^{[13]}$. Moreover, DNA damage and mutation were detected in $H$. armigera and Rhyzopertha dominica treated with various plant oils ${ }^{[14]}$.

Ecotoxicological research is focusing on studying environmental risk assessments using the comet assay (alkaline single cell gel electrophoresis), which was approved by the Committee on Mutagenicity Guidelines of the UK Department of Health (COM). It is qualitatively and quantitatively used in genotoxicity studies to assess DNA damage upon exposure to insecticides ${ }^{[15]}$, and in environmental monitoring of pollutants ${ }^{[16]}$.

The present study aimed to investigate the insecticidal toxicity of six essential oils against $S$. littoralis, with special reference to their toxic effects on the DNA and the detoxifying enzyme activities of $S$. littoralis to clarify their insecticidal mechanism. Data obtained from this study can explain to what extent we can use essential oils successfully as environmentally safe control agents in integrated pest-management (IPM) programs.

\section{MATERIAL AND METHODS \\ Collection and rearing of $S$. littoralis}

A laboratory susceptible strain of the cotton leafworm, S. littoralis was obtained as egg masses from the research division of the cotton leafworm, Plant Protection Research Institute (PPRI), Agricultural Research Center (ARC), Giza, Egypt. It was reared on castor bean leaves ever since free from any insecticidal exposure for more than 10 generations under laboratory conditions $\left(26 \pm 2^{\circ} \mathrm{C}, 65 \pm 10 \%\right.$ relative humidity and 8:16 light: dark photoperiod.

\section{Plant essential oils}

Six essential oils from clove (Syzygium aromaticum), crane's-bills (Geranium sp.), citronella (Cymbopogon sp.), dill (Anethum graveolens), cinnamon (Cinnamomum camphora), and basil (Ocimum basilicum) were used in this investigation. They were 
obtained from Delta Aromatic Co., Ltd, Giza, Egypt.

\section{Toxicity assay of the plant essential oils}

To determine the toxicity of the essential oils, the leaf-dipping technique was followed ${ }^{[14]}$. To determine the lethal concentration $\left(\mathrm{LC}_{50}\right)$ and $\mathrm{LC}_{90}$, five concentrations were prepared in distilled water using $0.5 \%$ Triton $^{\mathrm{TM}} \mathrm{X}-100$ (Sigma-Aldrich Corp., St. Louis, MO, USA), as a surfactant. For each concentration, castor leaves were dipped in each oil extract for 10 seconds then air-dried. Thirty of $3^{\text {rd }}$ or $5^{\text {th }} S$. littoralis larval instars were placed on the treated leaf surface, while leaves dipped in the sterile water served as control. Three replicates were set up for each concentration with different patches of larvae at different times. Treated leaves were removed after 24 hours and replaced with fresh ones for additional 24 hours. Mortality percentage was recorded after 48 hours and corrected according to Abbott's formula ${ }^{[17]}$. $\mathrm{LC}_{50}$ and $\mathrm{LC}_{90}$ were estimated according to Finney ${ }^{[18]}$ using "LdPLine ${ }^{\circ}$ " software (http://www. ehabsoft.com/ldpline).

\section{Assay of the detoxification enzymes}

One gram of third and fifth instar larvae of $S$. littoralis treated with $\mathrm{LC}_{50}$ of the essential oils under investigation was homogenized in $5.0 \mathrm{~mL}$ distilled water using chilled glass Teflon tissue homogenizer (ST-2 Mechanic-Preczyina, Poland). Homogenates were centrifuged at $8000 \mathrm{rpm}$ for 15 minutes at $5^{\circ} \mathrm{C}$; supernatants were kept at $-20^{\circ} \mathrm{C}$ until use. Total protein content was determined according to the method of Bradford ${ }^{[19]}$; the absorbance was measured at $595 \mathrm{~nm}$ using UV/visible spectrophotometer (Spectronic 1201, Milton Roy, Houston, TX, USA).

The AChE and CE activities were measured in the larval homogenates according to Simpson et $a l^{[20]}$ and Han et $a .^{[21]}$ using acetylcholine bromide and $\alpha$-naphthyl acetate as substrates, respectively. The GST activity was determined in the larval homogenates according to the method of Habig et al. ${ }^{[22]}$ using 1-chloro2,4 ,-dinitrobenzene, the increment in the absorbance was measured at $340 \mathrm{~nm}$. All used chemicals for assaying the detoxification enzymes were purchased from Sigma-Aldrich Corp.

\section{Comet assay}

Single strand breaks in the DNA of $S$. littoralis larvae treated with $\mathrm{LC}_{50}$ of selected plant essential oils were detected using the comet assay according to Singh et $a l .{ }^{[23]}$ and Tice et $a l^{[24]}$. A negative control was constructed using only water and Triton ${ }^{\mathrm{TM}} \mathrm{X}-100 \quad(0.5 \%)$. For preparing single-cell suspensions, larval midgut tissue was minced using a fine scissor then incubated with collagenase. Ethylenediaminetetraacetic acid was added to stop endonuclease activity; then dimethyl sulfoxide was added to prevent DNA damage by oxidation. Cell viability was examined using trypan blue ${ }^{[25]}$. Living cells that repelled the blue dye were counted using a light microscope. A generalized scheme for comet assay includes preparation of microscope slides with cells layered in the low melting agarose, cell lysis for liberating DNA, alkaline treatment $(\mathrm{pH}=13)$ to free single-stranded DNA, electrophoresis, neutralization, DNA staining using a fluorochrome stain, and visualization of comet for scoring using fluorescent microscope ${ }^{[24]}$. The commercially available software for comet assay (Comet Assay IV, https://www.inst em.com/solutions/genetic-toxicology/cometassay.php) was used to calculate the amount of DNA migrated in the tail (percentage of DNA in the tail), the length of the migrated DNA (tail length), and the tail moment. The DNA damage was scored in 50-100 randomly selected nuclei for each sample (three replicates per treatment). All used chemicals for comet assay were purchased from Sigma-Aldrich Corp.

\section{Data analysis}

Data were analyzed using one-way analysis of variance (ANOVA), followed by Tukey's method of multiple comparison, using a statistical program for Minitab 16.0 (Minitab Ltd., Coventry, UK). Significance level was tested at $P \leq 0.05$. 


\section{RESULTS}

Toxicity of plant essential oils against S. littoralis larvae

The obtained data showed variable toxic effects of the tested essential oils on the $3^{\text {rd }}$ and $5^{\text {th }}$ instar larvae of $S$. littoralis (Tables 1 and 2). Increasing essential oil concentration elevated significantly $(\mathrm{r}=0.9$, $P \leq 0.05)$ the cumulative mortality percentage of exposed $S$. littoralis larvae for 48 hours. The basil and dill oils were found to be the most toxic oils to both larval instars followed by cinnamon, clove, and citronella; $\mathrm{LC}_{50}$ values were $0.42,0.70,0.89,2.29$, and $2.66 \%$ for the $3^{\text {rd }}$ instar larvae, and $0.62,0.49,0.88,2.35$, and $1.39 \%$ for the $5^{\text {th }}$ instar larvae, respectively. The order of oil toxicity was fairly constant between both instars. The crane's-bills oil was the least toxic oil for both larval instars $\left(\mathrm{LC}_{50}\right.$ equals $4.56 \%$ and $4.52 \%$ for the $3^{\text {rd }}$ and $5^{\text {th }}$ instar larvae, respectively).

Table 1: Toxicity of the tested plant essential oils against the $3^{\text {rd }}$ instar larvae of the cotton leafworm, Spodoptera littoralis.

\begin{tabular}{lcccc}
\hline Plant oil & LC Values (\%) & 95\% Fiducial Limits & Slope \pm SE & R Values \\
\hline Basil & $\mathrm{LC}_{50}(0.42)$ & $(0.13-0.63)$ & $1.38 \pm 0.15$ & 0.94 \\
\multirow{3}{*}{ Cinnamon } & $\mathrm{LC}_{90}(43.56)$ & $(2.79-24.06)$ & & \\
& $\mathrm{LC}_{50}(0.89)$ & $(0.44-1.69)$ & $1.80 \pm 0.15$ & 0.95 \\
Citronella & $\mathrm{LC}_{90}(4.58)$ & $(4.20-28.59)$ & & \\
& $\mathrm{LC}_{50}(2.66)$ & $(1.70-3.70)$ & $2.32 \pm 0.22$ & 0.96 \\
Clove & $\mathrm{LC}_{90}(9.46)$ & $(7.87-26.75)$ & & \\
& $\mathrm{LC}_{50}(2.29)$ & $(2.04-2.56)$ & $2.55 \pm 0.26$ & 0.98 \\
Crane's-bills & $\mathrm{LC}_{90}(7.32)$ & $(6.02-9.69)$ & & \\
\multirow{3}{*}{ Dill } & $\mathrm{LC}_{50}(4.56)$ & $(3.66-6.66)$ & $1.33 \pm 0.25$ & 0.99 \\
& $\mathrm{LC}_{90}(41.95)$ & $(19.89-64.01)$ & & \\
& $\mathrm{LC}_{50}(0.70)$ & $(0.36-0.93)$ & $2.19 \pm 0.20$ & 0.87 \\
\hline
\end{tabular}

LC: lethal concentration, SE: standard error.

Table 2: Toxicity of the tested plant essential oils against the $5^{\text {th }}$ instar larvae of the cotton leafworm, Spodoptera littoralis.

\begin{tabular}{|c|c|c|c|c|}
\hline Plant oil & LC Values (\%) & 95\% Fiducial Limits & Slope \pm SE & R Values \\
\hline \multirow[t]{2}{*}{ Basil } & $\mathrm{LC}_{50}(0.62)$ & $(0.43-0.82)$ & $0.94 \pm 0.10$ & 0.99 \\
\hline & $\mathrm{LC}_{90}(14.21)$ & (7.10-51.07) & & \\
\hline \multirow[t]{2}{*}{ Cinnamon } & $\mathrm{LC}_{50}(0.88)$ & $(0.70-1.09)$ & $1.28 \pm 0.10$ & 0.96 \\
\hline & $\mathrm{LC}_{90}(8.90)$ & $(5.70-17.56)$ & & \\
\hline \multirow[t]{2}{*}{ Citronella } & $\mathrm{LC}_{50}(1.39)$ & $(0.94-1.79)$ & $1.30 \pm 0.20$ & 0.94 \\
\hline & $\mathrm{LC}_{90}(13.44)$ & $(8.90-28.06)$ & & \\
\hline \multirow[t]{2}{*}{ Clove } & $\mathrm{LC}_{50}(2.35)$ & $(2.09-2.61)$ & $2.63 \pm 0.27$ & 0.96 \\
\hline & $\mathrm{LC}_{90}(7.23)$ & $(5.98-9.47)$ & & \\
\hline \multirow[t]{2}{*}{ Crane's-bills } & $\mathrm{LC}_{50}(4.52)$ & $(3.50-5.25)$ & $1.13 \pm 0.24$ & 0.97 \\
\hline & $\mathrm{LC}_{90}(61.71)$ & $(24.06-95.27)$ & & \\
\hline \multirow[t]{2}{*}{ Dill } & $\mathrm{LC}_{50}(0.49)$ & $(0.09-0.85)$ & $0.61 \pm 0.17$ & 0.98 \\
\hline & $\mathrm{LC}_{90}(60.58)$ & $(15.75-63.19)$ & & \\
\hline
\end{tabular}

LC: lethal concentration, SE: standard error. 
Effect of the plant essential oils on the activity of the detoxification enzymes of S. littoralis larvae

The AChE activity increased significantly $(P \leq 0.05)$ in $3^{\text {rd }}$ instar larvae of $S$. littoralis upon exposure to $\mathrm{LC}_{50}$ of crane's-bills, basil, dill, citronella, and clove oils in comparison with the control larvae (Table 3). The maximum fold change in enzyme activity (1.79 fold) was recorded after crane's-bills oil treatment. In contrast, the activity of AChE decreased significantly $(P \leq 0.05)$ with exposure to cinnamon oil. On the other hand, a significant increase (1.37 fold) in AChE activity was recorded in the $5^{\text {th }}$ instar larvae upon exposure to basil oil, while a significant decrease in the enzyme activity was observed after clove, citronella, crane's-bills, cinnamon, and dill oils treatment, as compared with the control larvae (Table 4).

A significant elevation $(P \leq 0.05)$ of the activity of GST was recorded in the $3^{\text {rd }}$ instar larvae of $S$. littoralis treated with $\mathrm{LC}_{50}$ of both clove and cinnamon oils in comparison with the control larvae (Table 3). However, treatment with dill, crane's-bills, basil, and citronella oils decreased significantly $(P \leq 0.05)$ the activity of GST, as compared with the control larvae. The $5^{\text {th }}$ instar larvae treated with all essential oils showed a significant elevation $(P \leq 0.05)$ in the GST activity, except citronella that did not significantly affect $(P>0.05)$ the GST activity (Table 4).

In the $3^{\text {rd }}$ instar larvae, crane's-bills oil elevated significantly $\mathrm{CE}$ activity $(P \leq 0.05)$ followed by basil, citronella, and cinnamon oils, as compared with the control larvae (Table 3). The dill and clove oils decreased significantly the enzyme activity $(P \leq 0.05)$. On the other hand, the $5^{\text {th }}$ instar larvae showed a significant decrease in enzyme activity upon exposure to the basil, citronella, dill, and crane's-bills oils, while clove oil did not affect CE activity (Table 4).

Table 3: Effect of the tested plant essential oils on the acetylcholinesterase (AChE), glutathione S-transferase (GST), and carboxylesterase (CE) activities of the $3^{\text {rd }}$ instar larvae of the cotton leafworm, Spodoptera littoralis.

\begin{tabular}{lccc}
\hline & AChE activity & GST activity & CE activity \\
& $(\mu \mathrm{g}$ AChBr/min/mL) & $(\mu \mathrm{L} / \mathrm{min} / \mathrm{mL})$ & $(\mu \mathrm{L} / \mathrm{min} / \mathrm{mL})$ \\
& Mean $\pm \mathrm{SD}$ & Mean $\pm \mathrm{SD}$ & Mean $\pm \mathrm{SD}$ \\
& $($ Fold change $)$ & $($ Fold change $)$ & $($ Fold change $)$ \\
\cline { 2 - 4 } Control & $153.33 \pm 9.87^{\mathrm{d}}$ & $74.33 \pm 3.79^{\mathrm{b}}$ & $71.80 \pm 3.83^{\mathrm{b}}$ \\
Basil oil & $252.33 \pm 6.81^{\mathrm{ab}}$ & $56.67 \pm 2.08^{\mathrm{c}}$ & $81.47 \pm 3.97^{\mathrm{c}}$ \\
& $(1.64)$ & $(0.76)$ & $(1.13)$ \\
Cinnamon oil & $135.00 \pm 9.54^{\mathrm{d}}$ & $85.67 \pm 4.04^{\mathrm{a}}$ & $76.27 \pm 3.36^{\mathrm{b}}$ \\
& $(0.88)$ & $(1.15)$ & $(1.06)$ \\
Citronella oil & $221.00 \pm 6.08^{\mathrm{bc}}$ & $55.67 \pm 2.08^{\mathrm{c}}$ & $77.03 \pm 1.50^{\mathrm{c}}$ \\
& $(1.44)$ & $(0.75)$ & $(1.07)$ \\
Clove oil & $191.67 \pm 9.71^{\mathrm{c}}$ & $82.67 \pm 4.93^{\mathrm{a}}$ & $55.87 \pm 2.36^{\mathrm{d}}$ \\
& $(1.25)$ & $(1.11)$ & $(0.78)$ \\
Crane's-bills oil & $275.00 \pm 21.80^{\mathrm{a}}$ & $60.33 \pm 3.21^{\mathrm{c}}$ & $95.77 \pm 3.91^{\mathrm{a}}$ \\
& $(1.79)$ & $(0.81)$ & $(1.33)$ \\
Dill oil & $215.33 \pm 5.51^{\mathrm{c}}$ & $71.67 \pm 3.06^{\mathrm{b}}$ & $44.17 \pm 4.25^{\mathrm{e}}$ \\
& $(1.40)$ & $(0.96)$ & $(0.62)$ \\
\hline
\end{tabular}

Fold change was clculated by deviding the mean of enzyme activity in each oil group with its respective value in the control group. SD: standard deviation. Columns designated by different letters are significantly different $(P \leq 0.05)$. 
Table 4: Effect of the tested plant essential oils on the acetylcholinesterase (AChE), glutathione S-transferase (GST), and carboxylesterase (CE) activities of the $5^{\text {th }}$ instar larvae of the cotton leafworm, Spodoptera littoralis.

\begin{tabular}{lccc}
\hline & AChE activity & GST activity & CE activity \\
& $(\mu \mathrm{g} \mathrm{AChBr} / \mathrm{min} / \mathrm{mL})$ & $(\mu \mathrm{L} / \mathrm{min} / \mathrm{mL})$ & $(\mu \mathrm{L} / \mathrm{min} / \mathrm{mL})$ \\
& Mean $\pm \mathrm{SD}$ & Mean $\pm \mathrm{SD}$ & Mean $\pm \mathrm{SD}$ \\
& $($ Fold change $)$ & $($ Fold change $)$ & $($ Fold change $)$ \\
\cline { 2 - 4 } Control & $191.00 \pm 11.53^{\mathrm{d}}$ & $60.67 \pm 4.04^{\mathrm{b}}$ & $73.50 \pm 3.22^{\mathrm{a}}$ \\
Basil oil & $262.0 \pm 17.09^{\mathrm{a}}$ & $78.00 \pm 2.00^{\mathrm{ac}}$ & $65.67 \pm 2.58^{\mathrm{b}}$ \\
& $(1.37)$ & $(1.29)$ & $(0.89)$ \\
Cinnamon oil & $170.00 \pm 10.30^{\mathrm{bc}}$ & $72.40 \pm 2.40^{\mathrm{c}}$ & $60.33 \pm 3.51^{\mathrm{b}}$ \\
& $(0.89)$ & $(1.19)$ & $(0.82)$ \\
Citronella oil & $142.00 \pm 16.52^{\mathrm{e}}$ & $60.00 \pm 4.36^{\mathrm{ab}}$ & $59.43 \pm 2.40^{\mathrm{b}}$ \\
& $(0.74)$ & $(0.99)$ & $(0.81)$ \\
Clove oil & $182.33 \pm 6.81^{\mathrm{c}}$ & $76.00 \pm 1.50^{\mathrm{c}}$ & $73.07 \pm 2.68^{\mathrm{a}}$ \\
& $(0.95)$ & $(1.25)$ & $(0.99)$ \\
Crane's-bills oil & $138.33 \pm 7.64^{\mathrm{e}}$ & $86.00 \pm 5.29^{\mathrm{e}}$ & $38.13 \pm 1.80^{\mathrm{d}}$ \\
& $(0.72)$ & $(1.42)$ & $(0.52)$ \\
Dill oil & $122.00 \pm 12.12^{\mathrm{e}}$ & $99.67 \pm 3.51^{\mathrm{d}}$ & $45.87 \pm 2.87^{\mathrm{c}}$ \\
& $(0.64)$ & $(1.64)$ & $(0.62)$ \\
\hline
\end{tabular}

Fold change was clculated by deviding the mean of enzyme activity in each oil group with its respective value in the control group. SD: standard deviation. Columns designated by different letters are significantly different $(P \leq 0.05)$.

Effect of plant essential oils on the DNA of S. littoralis larvae

The effect of plant essential oils on $S$. littoralis DNA damage, as a result of comet assay, was shown in Figure "1". The control cells showed the normal appearance of nuclei with minimal damage. Essential oils posed a slightly significant effect $(P \leq 0.05)$ on DNA strand break expressed as a tail. In addition, essential oils showed variable effects on $S$. littoralis DNA in cells. The damage was either affecting the DNA by forming shorter tail (as in treatments with basil and dill oils) or is expressed in an increased tail length (as in case of the rest of the oils). In terms of DNA (\%), the maximum amount of DNA was recorded in cells treated with basil oil, while treatment with crane's-bills oil showed minimal effect. Considering the tail length, it was obvious that clove, citronella and crane's-bills oils enhanced the broken DNA strand migration forming a longer tail than that formed in case of treatment with basil, dill, and cinnamon oils, which might release larger DNA fragments that have lower migration ability, thus forming shorter tail but with more DNA.

\section{DISCUSSION}

Plant essential oils became one of the most substantial insect control agents worldwide $^{[26]}$. The flower and vegetable essential oils were tested for their anti-feeding, repellent, and oviposition-deterrent effects expressing a toxic effect on insects based on the Reregistration Eligibility Decision (RED) document issued by the Environmental Protection Agency (EPA) ${ }^{[8]}$. In the present study, the toxic effect of some essential oils from clove, crane's-bills, citronella, dill, cinnamon, and basil proved its possible implementation as a bio-control method in IPM programs to control $S$. littoralis. 


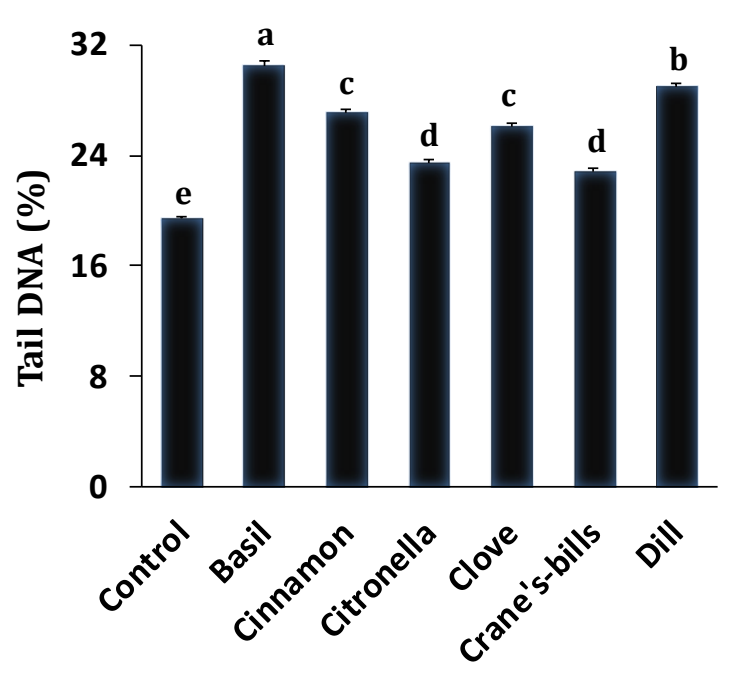

Plant Oils

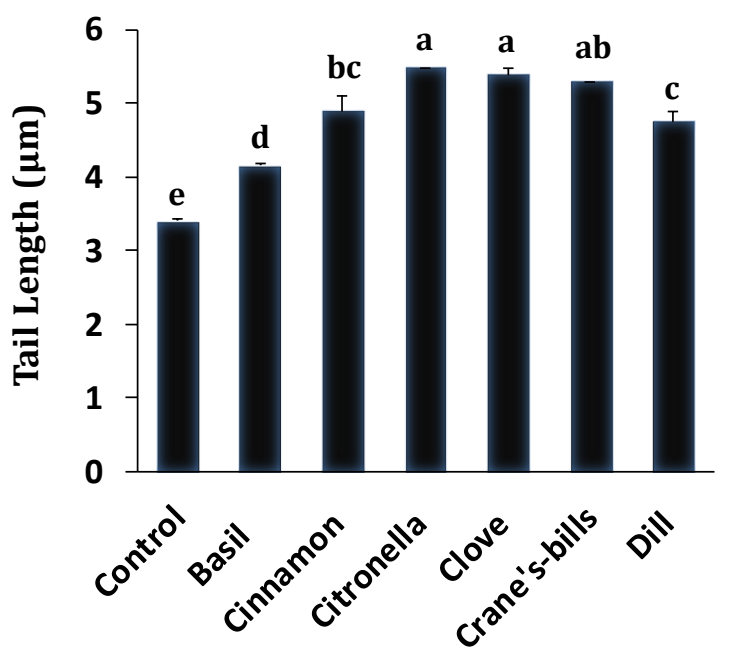

Plant Oils

It is valuable to highlight that the recorded $3^{\text {rd }}$ and $5^{\text {th }}$ instar larval mortality, upon treatment with the tested essential oils, emphasized its promising insecticidal activity within the first 48 hours after application. Such a short duration for achieving mortality (lethal time) is a beneficial character for a chemical agent against polyphagous pest larvae; hence preventing the destructive defoliating effect of larval activity. Similar results were obtained after treating the $4^{\text {th }}$ instar larvae of $S$. littoralis with castor and camphor oils; a highly toxic effect was recorded ${ }^{[27]}$. The clove oil showed a toxic effect on Tineola bisselliella after treatment to woolen fabrics, the effect was not persistent, thus a multiple application strategy was recommended ${ }^{[28]}$. Lingathurai

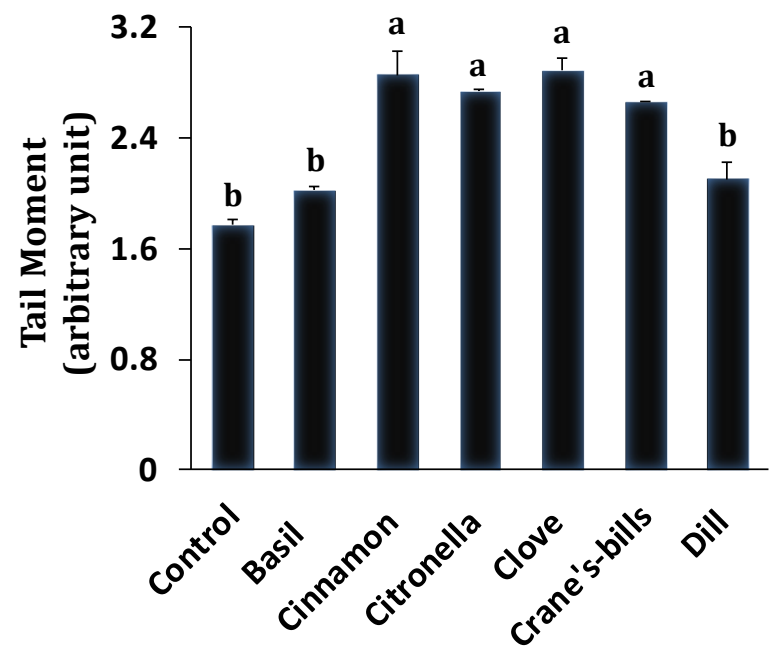

Plant Oils

Figure 1: Tail DNA (\%), tail length $(\mu \mathrm{m})$, and tail moment (arbitrary unit) in midgut cells of $S$. littoralis larvae treated with plant essential oils. Columns of the same parameter designated by different letters are significantly different $(P \leq 0.05)$.

et $a{ }^{[29]}$ recorded a highly toxic effect of many essential oils against larvae of the oblique banded leaf roller, Choristoneura rosaceana and Trichoplusia ni. In addition, Thymus vulgaris, Syzygium aromaticum, Cymbopogon citrates, Cinnamomum cassia, and Cymbopogon nardus residues were recorded as toxic oils against $T . n i^{[30]}$. The effect of the clove and citronella oil combination increased the repellency and toxicity of these essential oils against T. bisselliella ${ }^{[28]}$. Essential oils, such as basil, may express repellent, toxic, or oviposition deterrent effect on various insects (Dryophthoridae, Curculionidae, Bostrichidae, Tenebrionidae, Bruchidae, and Gelechiidae $)^{[31,32]}$. Similar results were obtained in attaining up to $100 \% 3^{\text {rd }}$ instar 
larval mortality of the fall armyworm " $S$. frugiperda" through ingestion bioassay $^{[33]}$.

In the present study, the plant essential oils induced larval mortality during the first 24 to 48 hours indicating their potency against $S$. littoralis larvae. Topical application was also considered as another assay for evaluating the toxicity of the essential oils against $S$. littoralis $^{[34]}$. The essential oils toxicity was evaluated and promising results were obtained against various insect orders including Hymenoptera, Isoptera, Coleoptera, and Diptera ${ }^{[35]}$. Considering order susceptibility, lepidopteran species were more susceptible to the essential oils than coleopterans ${ }^{[35]}$. The essential oils toxicity was evaluated against $S$. exigua at 24,48 , and 72 hours causing more than $80 \%$ larval mortality during the first 24 hours with the incidence of death during the first minute posttreatment ${ }^{[36]}$.

Agrochemical metabolism involves many enzymes including cytochrome P450 monooxygenases, GST and carboxyl/cholineesterases. The activity of theses enzymes explained insect's complex immune modulation through the activation of the detoxification enzymes in order to metabolize secondary plant metabolites ${ }^{[37]}$. In the present study, the activity of some detoxifying enzymes was measured in S. littoralis larvae treated with $\mathrm{LC}_{50}$ of the essential oils investigated herein. The elevation in GST enzyme activity was recorded in the $5^{\text {th }}$ instar larvae; a more tolerant stage compared to the $3^{\text {rd }}$ one, the latter expressed a decrease in enzyme activity emphasizing the possible role of GST in essential oil detoxification. In accordance to our findings, GST enzyme activity decreased in the cotton bollworm " $H$. armigera" treated with $\mathrm{LC}_{50}$ of Artemisia annua essential oil ${ }^{[38]}$. S. littoralis treatment with camphor oil also led to modulation of physiological response including the activity of lipase, $\alpha$-amylase, and glucose-6-phosphate dehydrogenase enzymes ${ }^{[27]}$. The GST activity was a good candidate as a biomarker in monitoring plant extracts and insecticide-exposure in Callosobruchus maculatus and $S$. littoralis $^{[39]}$.

During the observation period in the present study, apparent symptoms were ranging from hyperactivity and convulsions, followed by paralysis or even morbidity and eventually death. These observations together with a significant change in AChE enzyme activity suggested a neurotoxic mode of action. Neurotoxicity symptoms including variable uncontrolled movements were observed immediately after larval treatment accompanied by larval paralysis 5.0 minutes post-treatment with recovery during 3-6 hours, assuming enzymatic detoxification of the oil's bioactive compounds ${ }^{[40,41]}$.

The CE-isozymes are a group of $\alpha / \beta$ hydrolase enzymes hydrolyzing carboxylester-containing compounds, such as agrochemicals, through addition of water molecule. Meanwhile, they have a dual function in lipid and xenobiotic metabolism including pesticides ${ }^{[42]}$. The enzyme either remains bound to the hydrolysis byproduct or hence is aged; its catalytic activity is lost, or it is released "regenerated" to retain its catalytic activity ${ }^{[43]}$. Since CE in insects exist in isoforms; so, the hydrolytic activity differs according to substrate used ${ }^{[43]}$. The variation in enzyme activity in the present work after essential oil treatment to larval food may be attributed for using one substrate; difference in isozyme pattern requires using variable substrates to quantify all isozymes activity. So, insect CEisozymes abundance and activity contribute to the toxicity of agrochemicals containing ester group. CE is considered as one of the possible mechanisms conferring resistance to essential oils in Oryzaephilus surinamensis L. (Coleoptera: Silvanidae) resistant strain $^{[44]}$; such situation of crossresistance is responsible for the tolerance towards the essential oils. It is of a major concern for the researchers to investigate the role of $\mathrm{CE}$ in xenobiotic metabolism and insecticide detoxification. 
The variation in esterase activity between $\mathrm{CE}$ and AChE may be because some individuals may have more $\mathrm{CE}$ titers than $\mathrm{AChE}$, and vice versa ${ }^{[45]}$. Different oils have different active ingredients with different stereoisomers, hence a stereospecific enzyme activity ${ }^{[46]}$. The significant induction of detoxifying enzymes upon treatment with some of the tested oils may consider, to some extent, one of the possible mechanisms of incidence of resistance. Therefore, the pest immune modulation through affecting variable metabolic pathways against xenobiotics including secondary plant metabolites should gain more attention ${ }^{[47]}$. Meanwhile, the development of insect resistance is expected to be slow for being biodegradable, posing less stress on the environment or pests, besides having low mammalian toxicity ${ }^{[41]}$. Generally speaking, induction and inhibition of detoxification enzymes are possible in response to allelechemicals; however, the role of detoxification enzymes was validated, in few cases, at the biochemical level only ${ }^{[47]}$.

The DNA damage resulted in the present study after essential oil treatment is considered low to mild damage based on visual scoring of comet assay, as it did not lead to formation of long tails, the situation that is common with strong genotoxicants as some insecticides ${ }^{[48]}$ or oxidizing agents like hydrogen peroxide ${ }^{[49]}$. The ideal phenotype of an apoptotic cell, with more than $80 \%$ DNA fragmented outside the cell, was not recorded at any of the examined cells; indicating that there might be a DNA repair process that is responsible for protecting the cell ${ }^{[49]}$. The relation between the incidence of DNA damage and plant essential oil treatment in insects was validated in some insects ${ }^{[13,50]}$. Treatment of adult C. quinquefasciatus mosquito with essential oils of $P$. corylifolia induced an increase in DNA damage with increasing comet tail length with $6.713 \%$ and $8.864 \%$ DNA damage ${ }^{[13]}$. In addition, treatment of $R$. dominica with essential oils of Citrus aurantium, Eruca sativa, Zingiber officinale, and Origanum majorana increased significantly the DNA damage ${ }^{[50]}$.

The information obtained in the present study, through integrating biomarker assays, might form a holistic and judicious analysis of the impact of plant-derived chemicals (as plant essential oils) on the target organism, as well as it highlighted its environmental safety. The correlation between comet, biomarkers, and toxicological response provides an assessment method of the insect response toward essential oil application, which may be considered in risk assessment concerning evaluating the decision of its future application in an IPM program.

In conclusion, the presented research highlighted the promising potential of the examined essential oils against larvae of S. littoralis, indicating the possibility of using these six essential oils in the development of new bio-pesticides in implementing an efficient IPM program. Further studies are recommended to evaluate the efficacy of these essential oils in the field, and to determine their safety on non-target insects.

\section{ACKNOWLEDGEMENTS}

The authors wish to express their deep gratitude to Prof. Dr. Ghada M. El-Bassiony and Prof. Dr. Hanan H. Awad (Entomology Department, Faculty of Science, Cairo University) for critical revising of the manuscript.

\section{CONFLICT OF INTEREST}

The authors declare no potential financial conflict of interest.

\section{AUTHORS' CONTRIBUTIONS}

YAF, HME, and HMH planned the study and designed all experiments. YAF and $\mathrm{HMH}$ carried out the experiments and performed the statistical analysis, summarized, discussed, and interpreted the results. YAF, HME, and $\mathrm{HMH}$ drafted the manuscript. All authors read and approved the manuscript. 


\section{REFERENCES}

[1] Sneh, B.; Schuster, S. and Broza, M. (1981). Insecticidal activity of Bacillus thuringiensis strains against the Egyptian cotton leafworm Spodoptera littoralis [Lep.: Nocutidae]. Entomophaga, 26: 179-190.

[2] Bisrat, D. and Jung, C. (2020). Insecticidal toxicities of three main constituents derived from Trachyspermum ammi (L.) Sprague ex Turrill fruits against the small hive beetles, Aethina tumida Murray. Molecules, 25(5): 1100 (DOI: 10.3390/molecules25051100).

[3] Isman, M. B. (2000). Plant essential oils for pest and disease management. Crop Protection, 19(8-10): 603608.

[4] Chen, L.; Liu, Y.; Liu, H. et al. (2015). Identification and expression analysis of MATE genes involved in flavonoid transport in blueberry plants. PLoS ONE 10(3): e0118578 (DOI : 10.1371/ journal.pone.0118578).

[5] Yazdani, E.; Sendi, J. J. and Aliakbar, A. (2013). Chemical composition, toxicity and physiological effects of essential oil of Rosemarinus officinalison lesser mulberry pyralid, Glyphodes pyloalis Walker (Lepidoptera: Pyralidae). J Crop Prot, 2(4): 461-476.

[6] Lingathurai, S.; Ezhil Vendan, S.; Gabriel Paulraj, M. et al. (2011). Antifeedant and larvicidal activities of Acalypha fruticosa Forssk. (Euphorbiaceae) against Plutella xylostella L. (Lepidoptera: Yponomeutidae) larvae. Journal of King Saud University (Science), 23: 11-16.

[7] Liao, M.; Xiao, J.-J.; Zhou, L.-J. et al. (2017). Chemical composition, insecticidal and biochemical effects of Melaleuca alternifolia essential oil on the Helicoverpa armigera. J Appl Entomol, 141(9): 721-728.
[8] Regnault-Roger, C.; Vincent. C. and Arnason, J. T. (2012). Essential oils in insect control: low-risk products in a high stakes world. Annu Rev Entomol, 57: 405-424.

[9] Liu, Z.; Zhang, Q.; Wu, X. et al. (2017). Insecticidal mechanism of wintergreen oil against the health pest Paederus fuscipes (Coleoptera: Staphylinidae). J Med Entomol, 55(1): 155-162 (DOI: 10.1093/jme/tjx162).

[10] Mohamed, M. A.; Mahdy, E. M. E.; Ghazy, A. M. et al. (2016). The activity of detoxifying enzymes in the infective juveniles of Heterorhabditis bacteriophora strains: purification and characterization of two acetylcholineesterases. Comp Biochem Physiol C Toxicol Pharmacol, 180: 11-22.

[11] Tak, J. H.; Jovel, E. and Isman, M. B. (2017). Effects of rosemary, thyme and lemongrass oils and their major constituents on detoxifying enzyme activity and insecticidal activity in Trichoplusia ni. Pestic Biochem Physiol, 140: 9-16.

[12] Cruz, G. S.; Teixeira, V. W.; De Oliveira, J. V. et al. (2015). Histological and histochemical changes by clove essential oil upon the gonads of Spodoptera frugiperda (JE Smith) (Lepidoptera: Noctuidae). Int J Morphol, 33(4): 1393-1400.

[13] Dua, V. K.; Kumar, A.; Pandey, A. C. et al. (2013). Insecticidal and genotoxic activity of Psoralea corylifolia Linn. (Fabaceae) against Culex quinquefasciatus Say, 1823. Parasites \& Vectors, 6: 30 (DOI: 10.1186/1756-3305-6-30).

[14] Packiam, S. M.; Emmanuel, C.; Baskar, K. et al. (2015). Feeding deterrent and genotoxicity analysis of a novel phytopesticide by using comet assay against Helicoverpa armigera (HÜbner) (Lepidoptera: Noctuidae). Brazil Arch Biol Technol, 58(4): 487493. 
[15] Augustyniak, M.; Gladysz, M. and Dziewięcka, M. (2016). The comet assay in insects-status, prospects and benefits for science. Mutat Res Rev Mutat Res, 767: 67-76.

[16] Valverde, M. and Rojas, E. (2009). Environmental and occupational biomonitoring using the comet assay. Mutat Res, 681: 93-109.

[17] Abbott, W. S. (1987). A method of computing the effectiveness of an insecticide. 1925. J Am Mosq Control Assoc, 3(2): 302-303.

[18] Finney, D. J. (1952). Probit Analysis: a statistical treatment of the sigmoid response curve. Cambridge University Press, Cambridge, England.

[19] Bradford, M. M. (1976). A rapid and sensitive method for the quantitation of microgram quantities of proteins utilizing the principles of protein-dye binding. Anal Biochem, 72: 248-254.

[20] Simpson, D. R.; Bulland, D. L. and Linquist, D. A. (1964). A semi micro technique for estimation of cholinesterase activity in boll weevils. Ann Entomol Soc Am, 57: 367-371.

[21] Han Y.; Wu S.; Li Y. et al. (2012). Proteomic and molecular analyses of esterases associated with monocrotophos resistance in Helicoverpa armigera. Pestic Biochem Physiol 104(3): 243-251.

[22] Habig, W. H.; Pabst, M. J. and Jakoby, W. B. (I974). Glutathione Stransferase. The first enzymatic step in mercapturic acid formation. J Biol Chem, 249(22): 7130-7139.

[23] Singh, N. P.; McCoy, M. T.; Tice, R. R. et al. (1988). A simple technique for quantitation of low levels of DNA damage in individual cells. Exp Cell Res, 175: 184-191.

[24] Tice, R. R., Agurell, E.; Anderson, D. et al. (2000). A single cell gel/comet assay: guidelines for in vitro and in vivo genetic toxicology testing. Environ Mol Mutagen, 35(3): 206-221.
[25] Pool-Zobel, B. L.; Guigas, C.; Klein, R. G. et al. (1993). Assessment of genotoxic effects by lindane. Food Chem Toxicol, 31(4): 271-283.

[26] Yi, C.-G.; Kwon, M.; Hieu, T. T. et al. (2007). Fumigant toxicity of plant essential oils to Plutella xylostella (Lepidoptera: Yponomeutidae) and Cotesia glomerata (Hymenoptera: Braconidae). J Asia-Pacific Entomol, 10(2): 157163.

[27] Ali, A. M. and Ibrahim, A. M. A. (2018). Castor and camphor essential oils alter hemocyte populations and induce biochemical changes in larvae of Spodoptera littoralis (Boisduval) (Lepidoptera: Noctuidae). J Asia-Pacific Entomol, 21(2): 631-637.

[28] Plarre, R.; Pöschko, M.; Prozell, S. et al. (1997). Effects of oil of cloves and citronellol, two commercially available repellents, against the webbing clothes moth Tineola bisselliella Hum. (Lepidoptera: Tineidae). J Pest Sci, 70: 45-50.

[29] Machial C. M.; Shikano, I.; Smirle, M. et al. (2010). Evaluation of the toxicity of 17 essential oils against Choristoneura rosaceana (Lepidoptera: Tortricidae) and Trichoplusia ni (Lepidoptera: Noctuidae). Pest Manag Sci, 66: 1116-1121.

[30] Jiang, Z. L.; Akhtar, Y.; Zhang, $X$. et al. (2012). Insecticidal and feeding deterrent activities of essential oils in the cabbage looper, Trichoplusia ni (Lepidoptera: Noctuidae). J Appl Entomol, 136: 191-202.

[31] Ogendo, J. O.; Kostyukovsky, M.; Ravid, U. et al. (2008). Bioactivity of Ocimum gratissimum L. oil and two of its constituents against five insect pests attacking stored food products. J Stored Prod Res, 44: 328-334. 
[32] Yarou, B. B.; Assogba Komlan, F.; Tossou E. et al. (2017). Efficacy of basil-cabbage intercropping to control insect pests in Benin, West Africa. Comm Appl Biol Sci, 82(2): 157-166.

[33] Negrini, M.; Fidelis, E. G.; Schurt, D. A. et al. (2019). Insecticidal activity of essential oils in controlling fall armyworm, Spodoptera frugiperda. Arq Inst Biol, 86: e1112018 (DOI: 10.1590/1808-165700 1112018).

[34] Pavela, R. (2005). Insecticidal activity of some essential oils against larvae of Spodoptera littoralis. Fitoterapia, 76: 691-696.

[35] Albuquerque, E. L.; Lima, J. K.; Souza, F. H. et al. (2013). Insecticidal and repellence activity of the essential oil of Pogostemon cablin against urban ants species. Acta Trop, 127(3): 181-186.

[36] Murcia-Meseguer, A.; Alves, T. J. S.; Budia, F. et al. (2018). Insecticidal toxicity of thirteen commercial plant essential oils against Spodoptera exigua (Lepidoptera: Noctuidae). Phytoparasitica, 46(3): 233-245.

[37] Ramsey, J. S.; Rider, D. S.; Walsh, T. K. et al. (2010). Comparative analysis of detoxification enzymes in Acyrthosiphon pisum and Myzus persicae. Insect Mol Biol, 19(2): 155-164.

[38] Mojarab-Mahboubkar, M.; Sendi, J. J. and Aliakbar, A. (2015). Effect of Artemisia annua L. essential oil on toxicity, enzyme activities, and energy reserves of cotton bollworm Helicoverpa armigera (Hübner) (Lepidoptera: Noctuidae). J Plant Protect Res, 55(4): 371-377.

[39] Hamama, H. M. and Fergani, Y. A. (2019). Toxicity and oxidative stress induced in Spodoptera littoralis (Boisduval) (Lepidoptera: Noctuidae) treated with some insecticides. African Entomol, 27(2): 523-531.
[40] Kostyukovsky, M.; Rafaeli, A.; Gileadi, C. et al. (2002). Activation of octopaminergic receptors by essential oil constituents isolated from aromatic plants: possible mode of action against insect pests. Pest Manag Sci, 58(11): 1101-1106.

[41] Isman, M. B.; Miresmailli, S. and Machial, C. (2011). Commercial opportunities for pesticides based on plant essential oils in agriculture, industry and consumer products. Phytochem Rev, 10(2): 197-204.

[42] Ross, M. K.; Streit, T. M. and Herring, K. L. (2010). Carboxylesterases: dual roles in lipid and pesticide metabolism. J Pestic Sci, 35(3): 257-264.

[43] Wheelock, C. E.; Shan, G. and Ottea, J. (2005). Overview of carboxylesterases and their role in the metabolism of insecticides. J Pestic Sci, 30(2): 75-83.

[44] Lee, S. E. (2002). Biochemical mechanisms conferring crossresistance to fumigant toxicities of essential oils in a chlorpyrifosmethyl resistant strain of Oryzaephilus surinamensis L. (Coleoptera: Silvanidae). J Stored Prod Res, 38(2): 157-166.

[45] Rickwood, C. J. and Galloway, T. S. (2004). Acetylcholinesterase inhibition as a biomarker of adverse effect: a study of Mytilus edulis exposed to the priority pollutant chlorfenvinphos. Aquat Toxicol, 67: 45-56.

[46] Stok, J. E.; Huang, H.; Jones, P. D. et al. (2004). Identification, expression, and purification of a pyrethroid-hydrolyzing carboxylesterase from mouse liver microsomes. J Biol Chem, 279(28): 2986329869.

[47] Kumrungsee, N.; Pluempanupat, W.; Koul, O. et al. (2014). Toxicity of essential oil compounds against diamondback moth, Plutella xylostella, and their impact on detoxification 
enzyme activities. J Pest Sci, 87: 721-729.

[48] Collins, A. R. (2004). The comet assay for DNA damage and repair: principles, applications, and limitations. Mol Biotechnol, 26(3): 249-261.

[49] Lorenzo, Y.; Costa, S.; Collins, A. R. et al. (2013). The comet assay, DNA damage, DNA repair and cytotoxicity: hedgehogs are not always dead. Mutagenesis, 28(4): 427-432.

[50] Qari, S. H.; Abdel-Fattah, N. A. H. and Shehawy, A. A. (2017). Assessment of DNA damage and biochemical responses in Rhyzopertha dominica exposed to some plant volatile oils. J Pharmacol Toxicol, 12(2): 87-96.

\section{How to cite this article:}

Fergani, Y. A.; Elbanna, H. M. and Hamama, H. M. (2020). Genotoxicity of some plant essential oils in cotton leafworm, Spodoptera littoralis (Lepidoptera: Noctuidae): the potential role of detoxification enzymes. Egyptian Journal of Zoology, 73: 53-66 (DOI: 10.12816/ejz.2020.28358.1029). 


\section{السُمية الجينية لبعض الزيوت النباتيه الأساسية في حشرة دودة ورق القطن \\ SPODOPTERA LITTORALIS (LEPIDOPTERA: NOCTUIDAE) النشاط المحتمل لإنزيمات إزالة السموم

\author{
ياسمين عادل فرجاني 1، هبه محمود البنا1، هبه محمد حمامه2

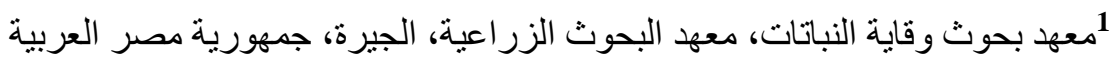 \\ 2سم علم الحشرات، كلية العلوم، جامعة القاهرة، الجيزة، جمهورية مصر العرة العربية
}

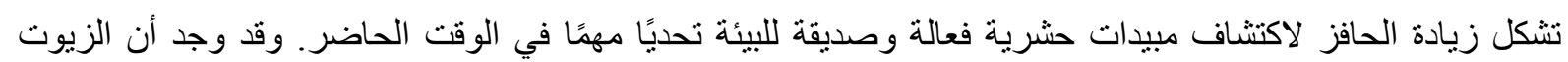

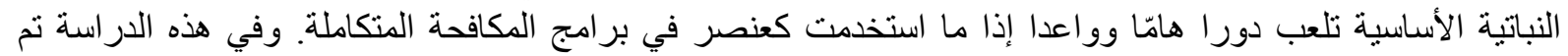

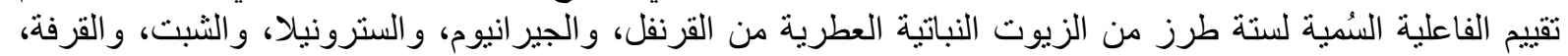

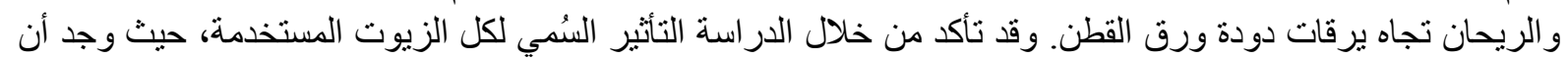

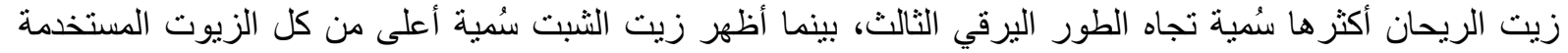

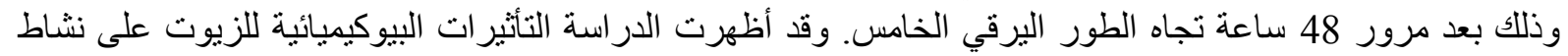

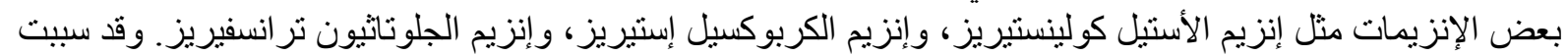

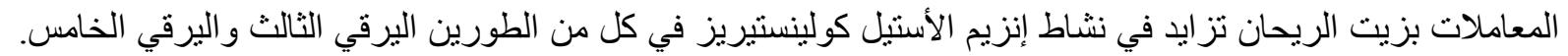

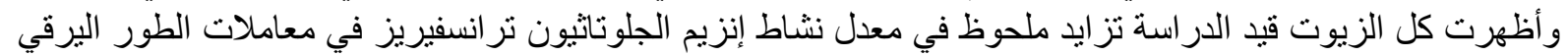

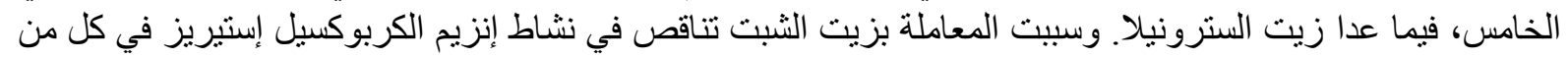

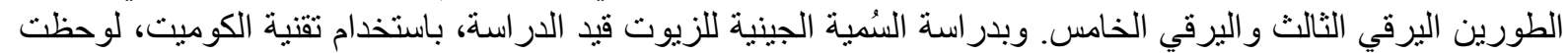

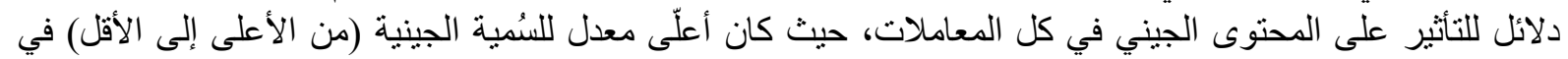

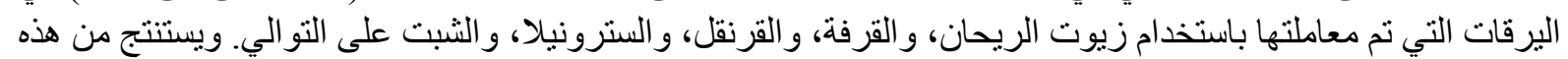

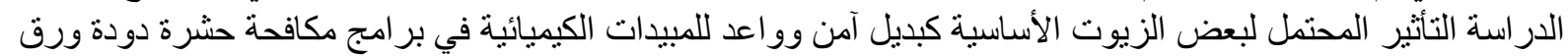
القطن. 